Ewa M. Guzik-Makaruk

\title{
TERRORISM AS A CURRENT THREAT TO CITIZENS' SECURITY
}

These days the word "terrorism" is in common use, not just by politicians, the media and those who practice the science of criminology and criminal law, but also by ordinary people. This modern supranational phenomenon is one of the occurrences that unite nations, organizations, and governments in the common idea of effective fight against its spread. After the events of 11 September 2001 in New York City and the bombings in Madrid and London, the mass media have popularized the notion that everyone must be afraid of a terrorist attack because it may take place at the least expected moment, as proven by several terrorist attacks. According to K. Liedel ${ }^{1}$, "all analyses show that the terrorist threat in Europe will increase and reach its peak around the year 2012. Everyone must be prepared for this. Especially in Poland, where there is so much discussion about CIA prisons and the torture of apprehended fundamentalists" ${ }^{\text {" }}$. The belief that Poland may become the target of terrorist attacks organized by Muslim fundamentalists is still nearly ubiquitous, as confirmed by $83 \%$ of respondents in a study conducted by the Public Opinion Research Center (CBOS) in 2005. ${ }^{3}$ Considering the social importance and gravity of the matter, it is worthwhile performing a true evaluation of the sense of threat posed by terrorism among Poles a few years after 2005 .

Terrorism is the subject of a study conducted within the framework of a research project entitled "Monitoring, identification, and countering of threats to citizens' security". The study was conducted in accordance with the poll method, since polls are the best way to conduct research in very large populations. The poll method is based on the principles of statistics and does not encompass the whole population, but only its part, preferably selected randomly, called a study sample. Due to the random

\footnotetext{
Director of the Terrorism Studies Center established in 2005 in Collegium Civitas in Warsaw. http://polska. $\mathrm{mil}$.pl/forum/viewtopic.php?t=4510\&sid=7b6ca3fb246f9fe9b31bed878bd6f72b.

"The sense of being threatened by terrorism and the accepted activities aimed at increasing the citizens' sense of security", report from research by CBOS, Warsaw, September 2005, http://www.cbos.pl/SPISKOM.POL/2005/ K_144_05.PDF, p. 2.

4 The project was performed by the Department of Criminal Law of the Faculty of Criminal Law of the University of Białystok in cooperation with the Jarosław Dąbrowski Military Technical Academy in Warsaw.
} 
nature of the sample, it reflects the characteristics of the population and allows for drawing statistical conclusions about the population, among others ascribing the results obtained in the study of the sample to the whole population. The research used the technique of a computer-supported direct questionnaire survey. The interviews were conducted on 24-30 September 2008 on a representative sample of adult Poles (over 18 years old). The study was conducted by the Pentor Research International research institute which for this purpose hired a group of about 150 trained pollsters. In total, 1042 surveys were held as a part of this research. This research sample can be considered as representative of the total population of Poland, with regards to gender, age, education, and place of inhabitance (size of towns and region) ${ }^{5}$

Table 1 below presents the structure of the sample with regards to the most important variables: gender, age, education, place of inhabitance, and family income.

Table 1. Structure of the research sample ${ }^{6}$

SAMPLE STRUCTURE N=1000 (Omnibus)

\begin{tabular}{|l|l|c|c|c|c|c|}
\hline I. & Gender & $\begin{array}{c}\text { Man } \\
48 \%\end{array}$ & $\begin{array}{c}\text { Woman } \\
52 \%\end{array}$ & \multicolumn{2}{|l|}{} \\
\hline II. & Age & $\begin{array}{c}29 \text { y.o. and } \\
\text { less } \\
29 \%\end{array}$ & $\begin{array}{c}30-39 \text { y.o. } \\
17 \%\end{array}$ & $\begin{array}{c}40-49 \text { y.o. } \\
17 \%\end{array}$ & $\begin{array}{c}50-59 \text { y.o. } \\
18 \%\end{array}$ & $\begin{array}{c}60 \text { y.o. and } \\
\text { more } \\
17 \%\end{array}$ \\
\hline III. & Education & $\begin{array}{c}\text { Elementary } \\
24 \%\end{array}$ & $\begin{array}{c}\text { Vocational } \\
27 \%\end{array}$ & $\begin{array}{c}\text { Secondary } \\
35 \%\end{array}$ & $\begin{array}{c}\text { Higher } \\
14 \%\end{array}$ & \\
\hline IV. & $\begin{array}{l}\text { Place of } \\
\text { inhabitance }\end{array}$ & $\begin{array}{c}\text { Village } \\
38 \%\end{array}$ & $\begin{array}{c}\text { under } 20 \\
\text { thousand } \\
\text { inhabitants } \\
11 \%\end{array}$ & $\begin{array}{c}20-50 \\
\text { thousand } \\
13 \%\end{array}$ & $\begin{array}{c}50-200 \\
\text { thousand } \\
21 \%\end{array}$ & $\begin{array}{c}\text { over } 200 \\
\text { thousand } \\
17 \%\end{array}$ \\
\hline V. & $\begin{array}{l}\text { Family } \\
\text { income }\end{array}$ & $\begin{array}{c}\text { PLN } 900 \text { and } \\
\text { less } \\
7 \%\end{array}$ & $\begin{array}{c}\text { PLN } 901-1,250 \\
7 \%\end{array}$ & $\begin{array}{c}\text { PLN } 1,251- \\
2,000 \\
22 \%\end{array}$ & $\begin{array}{c}\text { PLN } 2,001- \\
3,000 \\
20 \%\end{array}$ & $\begin{array}{c}\text { over PLN } \\
3,000 \\
14 \%\end{array}$ \\
\hline
\end{tabular}

Because further parts of this paper present a discussion on certain groups of respondents who live in specific regions of Poland, it is necessary to include the illustration below which shows the distribution of the research sample by region.

5 E. Glińska, A. Kowalewska, Report from study titled "Citizens' sense of security - social diagnosis of threats," conducted as a part of a research grant no. PBZ-MNiSW-DBO-01/1/2007, directed by prof. zW. dr hab (full professor) Emil W. Pływaczewski, titled 'Monitoring, identification, and countering of threats to citizens' security, Białystok, January 2009, p. 6-8. 


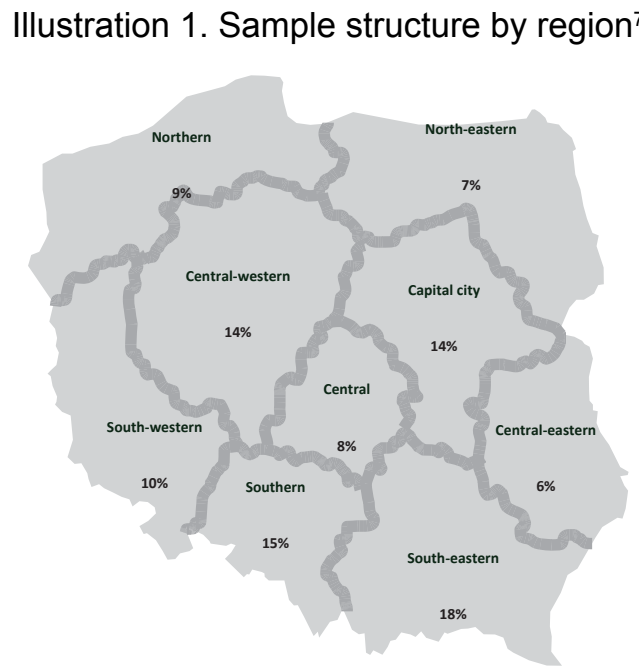

The research tool used is a highly standardized questionnaire which allows for asking all the respondents the same questions in the same order. A majority of the questions were closed questions where the respondents were asked to select an answer from a list prepared by the research team. ${ }^{8}$ The goal of the questionnaire consisted of translating the research objectives and problems into the individual survey questions. ${ }^{9}$

With regards to terrorism, the survey was divided into six groups of problems, which were aimed at gaining the following knowledge:

- answers to the question of whether terrorism is one of the threats that people are concerned about the most;

- opinion about the extent of the presence of the threat of terrorism;

- information on the level of fear of possible victimization in a terrorist crime;

- information on the actual victimization in terrorist crimes;

- social opinion on countering the threat of terrorism by the state and its organs;

- level of social acceptance of the state's intervention in citizens' privacy in order to eliminate the threat of terrorism.

The definition of terrorism was purposefully not defined in the questionnaire and the survey was based on the understanding of the term by the general population. Paradoxically, explaining what terrorism is could bring more harm than good to the

7 Drawing from: E. Glińska, A. Kowalewska, ibid., 9.

8 Staff of the University of Białystok, Faculty of Law, Institute of Criminal Law and Criminology: G.B. Szczygieł, K. Laskowska, E.M. Guzik-Makaruk, W. Filipkowski, E. Zatyka.

$9 \quad$ E. Glińska, A. Kowalewska, ibid., 9. 
survey. For many years, there have been academic arguments about the definition of terrorism, there is no single definition that everyone approves, and the literature includes over one hundred possible definitions ${ }^{10}$. Moreover, terrorism as a term is not present in the current law, although the Polish legislator uses various terms, such as a crime of terrorist nature and a terrorist attack.

The Penal Code does include a definition of a crime of terrorist nature. ${ }^{11}$ Art. $115 \S 20$ of the Penal Code provides that a crime of terrorist nature is an unlawful act that is subject to penalty of imprisonment with the upper limit of no less than 5 years. The act must be committed with the aim of gravely intimidating numerous persons; forcing an organ of public authorities of the Republic of Poland or another state, or an organ of an international organization, to take or desist from taking certain actions; or causing significant disruptions in the system of government or the economy of the Republic of Poland, another state, or an international organization. A threat to commit such an act also constitutes a terrorist crime.

A definition of a terrorist act, which does not necessarily correspond to the definition of a crime of terrorist nature, can be found in the act on countering introduction into the financial system of assets originating from illegal or unrevealed sources and on countering financing of terrorism. ${ }^{12}$ According to art. 2 (7) of this act, a terrorist act is defined as a crime against peace and humanity, as well as a war crime, a crime against public security, and a crime defined in art. 134 and art. 136 of the Penal Code. Even at first glance the definitions show how complicated the matter is and that it is better to rely on the respondents' own knowledge and understanding of terrorism.

\section{Re 1. Is terrorism one of the threats that people are concerned about the most?}

The respondents were asked to spontaneously indicate threats that in their opinion are detrimental to the safety of people ${ }^{13}$; afterwards, they were asked what they were afraid of the most ${ }^{14}$. Terrorism was among the threats that the respondents would list spontaneously, although only $11 \%$ of them did so. Thus, it appears that the threat of terrorism is not very prominent in social awareness.

The responses of the respondents with regards to identification of terrorism as a problem that is of personal concern to them and that affects their own sense of

\footnotetext{
10 K. Indecki, Prawo karne wobec terroryzmu i aktu terrorystycznego [Criminal law's response to terrorism and terrorist acts], Łódź: 1998, 22.

11 Act of 6 June 1997, Penal Code, Dz.U. [Journal of laws], 88: 1997, item 553, as amended.

12 Act of 16 November 2000 on countering introduction into the financial system of assets originating from illegal or unrevealed sources and on countering financing of terrorism, Dz.U. [Journal of laws], 153 (2003), item 1505, as amended.

13 See: the Annex at the end of the paper, titled "Excerpts from the Survey Questionnaire" - question 1.

14 Ibid., question 2.
} 
security were slightly different. An analysis of the respondents' spontaneous answers to the question "What are you concerned about the most?" leads to the conclusion that the respondents much more rarely list the types of large-scale threats that may concern the overall population, such as terrorism. Interestingly, as many as $14 \%$ of all respondents stated that they did not perceive any threats in their daily lives and that they did not think at all about such threats. This proves that, perhaps due to rationalization, respondents are more prone to ascribe fears and concerns caused by various reasons to other people than to admit such fears and concerns themselves. It also shows a certain optimism of the respondents with regards to the level of their own security, which may be caused by the lack of earlier negative experiences in this respect. ${ }^{15}$

Diagram 1. Differences in respondents' answers to the following questions: "What in your opinion are people concerned about the most?" and "What are you personally concerned about the most?"

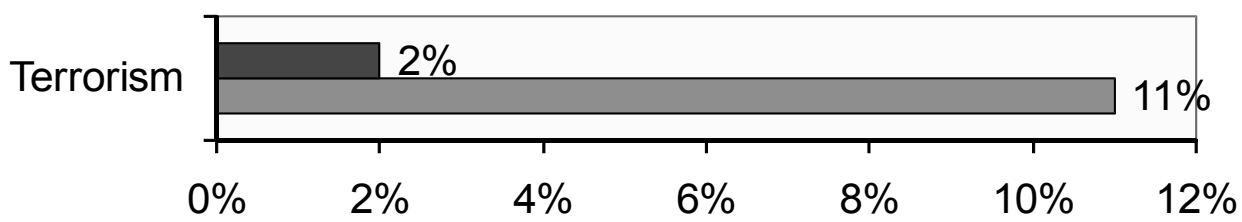

Diagram 1 above clearly demonstrates that one in ten respondents believe that people are concerned about terrorism, while only $2 \%$ of respondents list terrorism as their most important personal concern. It should be emphasized that respondents listed terrorism as the greatest threat to their security spontaneously, without any suggestions on the part of the pollster. ${ }^{16}$ Thus, only a small percentage of the population feels any significant concerns about terrorism.

In the next part of the survey, the respondents were asked about the extent to which they were concerned about threats to public security, including terrorist attacks, proposed in the survey. ${ }^{17}$ Table 2 below shows the distribution of the respondents' answers. 
Table 2. Supported identification of threats that

the respondents are concerned about the most

\begin{tabular}{|c|c|c|c|c|c||}
\hline $\begin{array}{c}\text { Are you concerned } \\
\text { about...? }\end{array}$ & $\begin{array}{c}\text { Definitely } \\
\text { concerned }\end{array}$ & $\begin{array}{c}\text { Rather } \\
\text { concerned }\end{array}$ & $\begin{array}{c}\text { Rather not } \\
\text { concerned }\end{array}$ & $\begin{array}{c}\text { Definitely not } \\
\text { concerned }\end{array}$ & It's hard to say \\
\hline Terrorist attacks & $13 \%$ & $24 \%$ & $44 \%$ & $17 \%$ & $1 \%^{*}$ \\
\hline
\end{tabular}

Situations where the totals of the percentages of all the answers are $99 \%$ or $101 \%$ are caused by the numbers being rounded up. The program that generates the statistics tables first calculates the percentages for the individual answers, with the precision of several digits past the decimal point, and then rounds them up to a full percentage. As a result, the sum of percentages for the individual answers can be $1 \%$ more or less than $100 \%$. Variations of $1-2 \%$ can also result from weighing of data.

As the table shows, as many as $37 \%$ of the respondents were concerned about terrorist attacks, but their answers were counterbalanced by opposite opinions, because $61 \%$ of respondents were not concerned about terrorist attacks, and one in six definitely rejected terrorist attacks as their personal threat. Interestingly, there is a fairly large disproportion between the answers where terrorism was spontaneously identified as a source of the greatest concern of the respondents $(2 \%)$ and the answers where the question identified terrorist attacks as a threat that the respondents were concerned about the most (37\% of responses). This is probably due to the fact that terrorist attacks are not present in the social awareness of Poles and they only emerge as a threat once a third party (pollster) mentions such a possibility.

The opinions about the threat caused by terrorist attacks were also influenced by the socio-demographic characteristics of the respondents. An analysis of the statistical data obtained in the study indicates that the threat of terrorist attacks is of the highest importance to women who live in Warsaw. ${ }^{18}$ Perhaps such a distribution of answers is due to the fact that in general women were a little more likely to admit that they did not feel secure. In regular circumstances $15 \%$ of women, versus $10 \%$ of men, felt insecure. ${ }^{19}$ Already in the 2005 study a personal sense of threat caused by terrorism was declared much more often by women $(64 \%)$ than men $(48 \%)^{20}$, but in the 2008 study these values were much lower (women $-44 \%$, men $-30 \%$ ), which indicates that in the period between these surveys the sense of personal security of respondents with regards to terrorist attacks increased. As a comment to the observed relationship between the gender and place of inhabitance (women living in Warsaw) and the level of personal concern about terrorism, it should mentioned that female inhabitants of Warsaw are aware of the fact that they live in the largest city in Poland, an important European political and economic center, and a seat of the government, which may become a potential objective of a terrorist attack.

18 E. Glińska, A. Kowalewska, ibid., 19, 20.

19 Ibid., 23.

20 The sense of being threatened by terrorism and the accepted activities aimed at increasing the citizens' sense of security, Report from research by CBOS, Warsaw, September 2005, http://www.cbos.pl/SPISKOM. POL/2005/K_144_05.PDF, p. 3. 


\section{Re 2. Opinions about the extent of the presence of the threat of terrorism}

Given the fact that recent years brought spectacular terrorist attacks in different parts of the world, which were reported in detail by the mass media, it was assumed that the phenomenon of terrorism is universally known and, thus, present in so- cial awareness. The respondents were asked about the presence of the threat of terrorism in Poland. The problem was divided into two categories: the threat of hostage-taking and the threat of terrorist attacks and bombings. ${ }^{21}$ The distribution of the answers to this question is shown in Diagram 2 below.

The public believes that the threat of terrorism in Poland is small. A large majority of the respondents (approximately 3/4ths) declared that the likelihood of terrorist attacks, bombings, and hostage-taking in Poland is either very low or fairly low. Only one in five or six respondents considered the likelihood of these threats to be high. Opinions that the likelihood was very high were very rare. Despite the low level of threat, the inhabitants of the capital city region were more often con cerned about them ${ }^{22}$, which most likely can be explained by the fact that Warsaw is the central point of the Polish state. The level of terrorist threat according to public opinion is shown in Diagram 2 below.

Diagram 2. Opinions on the level of terrorist threat

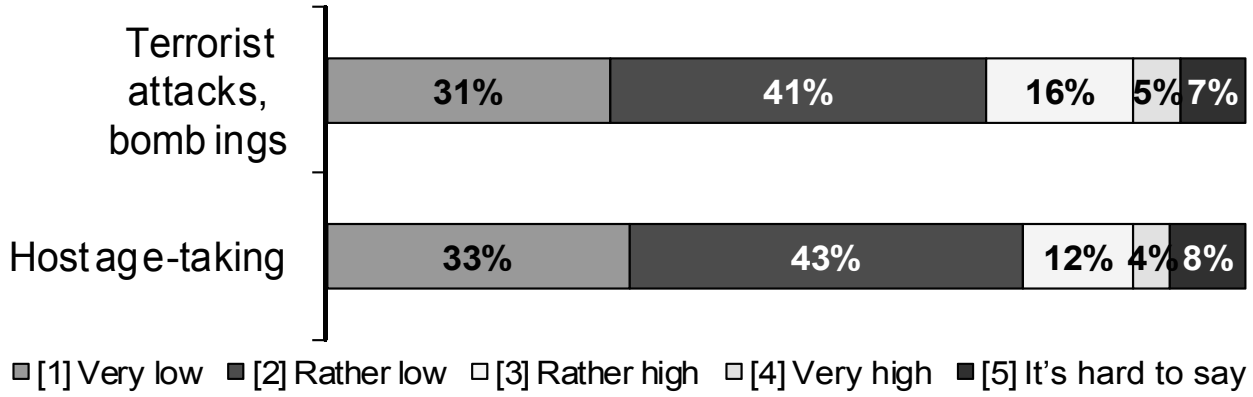

Nevertheless, it should be noted that the survey was conducted before the Polishgeologist was kidnapped and killed by the Taliban in Pakistan in February 2009. Perhaps the public sense of threat caused by terrorism would have been different if the survey was conducted during that period.

It should be noted that the Polish society is very strongly convinced that terrorism is not a real threat. On average, $75 \%$ of the respondents declared that the likelihood of terrorist attacks, bombings, and hostage-taking in Poland is either very low or fairly low. 


\section{Re 3. The level of fear of possible victimization in a terrorist crime}

To gain knowledge of the level of concern and fear of possible victimization by terrorism, the respondents were asked the question of whether they were personally concerned about becoming victims of terrorism. ${ }^{23}$ Unlike the question about the extent of the presence of terrorist threat in Poland, which focused on the presence of the threat and its potential social harm, this question focused on the psychological aspects of the problem. The aim was to study the sense of personal threat, as the awareness of the presence of the threat in Poland does not need to translate into personal sense of concern. Table 3 below demonstrates the results.

Table 3. Distribution of answers to the question of whether the respondent is concerned about becoming a victim of terrorism (\%)

\begin{tabular}{|c|c|c|c|c|c|}
\hline & $\begin{array}{c}\text { Definitely } \\
\text { concerned }\end{array}$ & $\begin{array}{c}\text { Rather } \\
\text { concerned }\end{array}$ & $\begin{array}{c}\text { Rather not } \\
\text { concerned }\end{array}$ & $\begin{array}{c}\text { Definitely not } \\
\text { concerned }\end{array}$ & $\begin{array}{c}\text { It's hard } \\
\text { to say }\end{array}$ \\
\hline A terrorist attack, a bombing & 2 & 11 & 44 & 38 & 5 \\
\hline Hostage-taking & 1 & 5 & 41 & 50 & 3 \\
\hline
\end{tabular}

As the above data indicates, terrorism is hardly ever a source of personal sense of insecurity. Only one in eight respondents (13\%) was concerned about terrorist attacks and bombings, to include $2 \%$ who had a high sense of insecurity. Hostagetaking, even though it was well-known to the respondents from films and media reports, was considered to be a rather distant threat: only $6 \%$ expressed their concern about it. There were no differences between the different socio-demographic groups of respondents with regards to their opinions about the above-mentioned threats. ${ }^{24}$

This shows that the social attitudes in this area were rather firm and that there is a very large group of respondents who perceived no personal threat and a small group who did. The subjective scale of the sense of threat caused by terrorism is displayed in Diagram 3 below. 
Diagram 3. Level of subjective sense of threat caused by terrorism

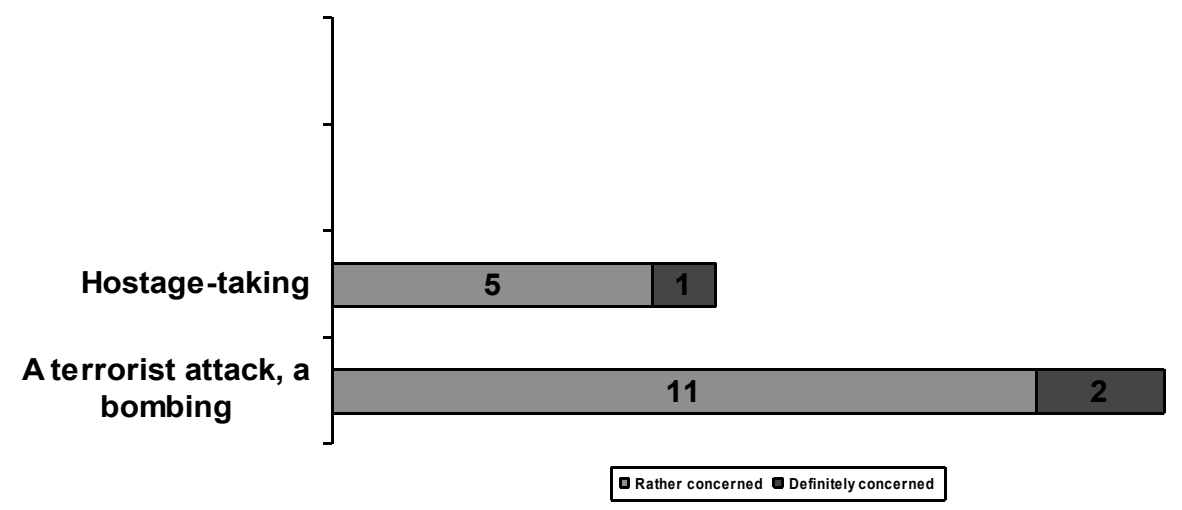

It should be noted that there is a certain disproportion in the study results. Even though $37 \%$ of respondents were concerned about terrorist attacks (Table 2), only $2 \%$ were personally concerned about becoming a victim of terrorism (Table 3, Diagram 3). The society does perceive a hypothetical danger of terrorism, but when more closely faced with the problem, only a few express their concerns about becoming victims of terrorist attacks or bombings.

\section{Re 4. Actual victimization in terrorist crimes}

The next question that the respondents were asked was a typical victimization survey aimed at finding out whether the respondents had been a victim of a crime and whether any of the people they knew had been a victim (the so-called indirect vic- timization experience). The respondents were asked whether they have ever been victims of hostage-taking and whether any members of their close family were such victims. For obvious reasons they were not asked whether they were victims of a terrorist attack or a bombing and instead they were asked whether members of their close family were such victims. ${ }^{25}$ The distribution of the answers to this question is shown in Diagram 4 below. 
Table 4. Threats that the respondent or a member of his/her close family was a victim of (\%)

\begin{tabular}{|c|c|c|}
\hline & The respondent was a victim & $\begin{array}{c}\text { A member of close family was } \\
\text { a victim }\end{array}$ \\
\hline A terrorist attack, a bombing & XXXXXXXXXXXXX & 1 \\
\hline Hostage-taking & 0 & 1 \\
\hline
\end{tabular}

As one could have assumed a priori, none in the group of over one thousand re spondents had been victimized in a hostage-taking, and only $1 \%$ of the respondents stated that their close family members were victims of hostage-taking, a terrorist attack, or a bombing. This shows a marginal extent of victimization of the Polish society by such crimes. The situation is further improved by the fact that the statistical error margin for the survey is $3.2 \%$. Thus, it can be conceded that actually no credible information has been obtained concerning actual victimization.

\section{Re 5. The social opinion on countering the threat of terrorism by the state and its organs}

The next question required the respondents to express their opinions regarding the countering of terrorism by the state and its organs. ${ }^{26}$ As Table 5 below shows, most respondents conceded that the state adequately countered the threat of terrorism.

Table 5. Countering of terrorist attacks, bombings, and hostage-taking by the state (\%)

\begin{tabular}{|c|c|c||}
\hline \hline & $\begin{array}{c}\text { The state does not counter } \\
\text { them adequately }\end{array}$ & $\begin{array}{c}\text { The state counters them } \\
\text { adequately }\end{array}$ \\
\hline Terrorist attacks, bombings & 36 & 64 \\
\hline Hostage-taking & 32 & 68 \\
\hline
\end{tabular}

In the whole study, which besides terrorism focused on about a dozen other categories of criminal activity (e.g. corruption, organized crime, common crime), the respondents considered the state to act the most effectively with regards to ter rorism. The social opinion on the countering of the threat of terrorism by the state and its organs is that it is quite satisfactory. It is hard to tell for what reasons the respondents have such a good opinion of the state organs, since terrorist crimes are among the most difficult to prevent effectively. Certainly the fact that for decades 
there have been no terrorist attacks in Poland does influence the positive opinions about the preventive activities of the state. Moreover, recently ${ }^{27}$ the government established the Antiterrorist Center (ATC), operating continuously, which cooperates with anti-terrorist centers in other countries. This event was broadcast in the media, which did influence public perception.

\section{Re 6. The level of social acceptance of the state's interference with citizens' privacy in order to eliminate the threat of terrorism}

Since terrorism is a fairly real threat to Polish society, the authors of the research considered it reasonable to perform a diagnosis of the population's readiness to give up some of their rights and freedoms to improve the security of the state and of what operational methods of services responsible for eliminating the threat of terrorism the respondents would be willing to accept. The purpose of the survey was to identify the level of acceptance of interference by the state with the privacy of Poles in order to enhance the effectiveness of actions by various agencies responsible for countering different threats.

The respondents were asked if, in the case of danger to citizens' security, interference of the state with their privacy was, in their opinion, acceptable or inacceptable. ${ }^{28}$ The respondents' opinions on this matter turned out to be very differentiated. Almost a half of all respondents (45\%) would accept interference of the state with their privacy, but only in exceptional situations. Nearly one in three survey participants $(28 \%)$ believed that interference of state agencies responsible for citizens' safety with their privacy should always be permitted. Only $12 \%$ of all respondents declared that interference of state agencies with their privacy should never be permitted. ${ }^{29}$

Considering the fact that nearly a half of all respondents would allow for interference of the state with their privacy, albeit in exceptional situations, they were asked to spontaneously define such exceptional situations. ${ }^{30}$ One in ten respondents declared that he or she would accept interference of the state with their privacy in the case of a terrorist threat.

This indicates that nearly $40 \%$ of respondents $(28 \%$ always and $10 \%$ in the exceptional situation of a terrorist threat) would allow the state to interfere with their privacy in the case of a terrorist threat. This percentage should be considered to be high and to indicate a high level of social acceptance of operational activities of state agencies aimed at eliminating the terrorist threat.

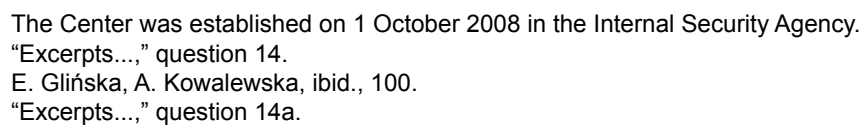


Afterwards, the respondents were reminded that in the fight against crime the state can use various forms of interference with citizens' privacy. The respondents were asked to express their opinions concerning the acceptable forms of interference with civic rights and freedoms in a situation where the respondents or someone in their families were threatened by terrorist activities ${ }^{31}$. The respondents were shown a list of various forms and methods of operational work, which had been prepared earlier. The list included the following forms and methods: telephone tapping; mail control, to include electronic mail; checking the content of a computer through the Internet (remote search of a computer); control of property; and three forms of monitoring: placing cameras in public places, placing cameras at work, and placing cameras in homes. The distribution of the answers to this question is shown in Table 6 below.

Table 6. Acceptable forms of the state's interference in its fight against terrorism

\begin{tabular}{|c|c|c|c|c|c|c|c|}
\hline $\begin{array}{c}\text { Telephone } \\
\text { tapping }\end{array}$ & $\begin{array}{c}\text { Mail } \\
\text { control, } \\
\text { to include } \\
\text { electronic } \\
\text { mail } \\
\text { the } \\
\text { content of } \\
\text { a computer } \\
\text { drive } \\
\text { through } \\
\text { the Internet }\end{array}$ & $\begin{array}{c}\text { Checking } \\
\text { property }\end{array}$ & $\begin{array}{c}\text { Placing } \\
\text { cameras in } \\
\text { public } \\
\text { places, } \\
\text { e.g. } \\
\text { streets, } \\
\text { stores, } \\
\text { parks }\end{array}$ & $\begin{array}{c}\text { Placing } \\
\text { cameras } \\
\text { at work }\end{array}$ & $\begin{array}{c}\text { Placing } \\
\text { cameras } \\
\text { in homes }\end{array}$ & None \\
\hline 67 & 58 & 59 & 34 & 66 & 46 & 34 & 10 \\
\hline
\end{tabular}

It should be noted that in the presence of terrorist threats a fairly large group of respondents would be willing to accept covert operations of state agencies that would limit their privacy. As many as $67 \%$ of respondents would accept tapping of their own phones. During the study conducted in 2005, telephone tapping and control of electronic mail were the most controversial - only $44 \%$ and $46 \%$ of respondents accepted such measures. ${ }^{32}$ The later research indicates that the percentage of Poles who approve of telephone taping in situations where terrorist threat is present has increased to $67 \%$ and the percentage who approve of mail control, to include electronic mail - to $58 \%$. Thus, acceptance of such forms of the state's interference with citizens' privacy in the presence of terrorist threats has increased.

Numerous groups of respondents (which in total amounted to approximately $60 \%$ of all respondents) would also be willing to accept installation of cameras in public places (66\%) and checking the content of computers through the Internet $(59 \%)$. Nearly a half of them would also accept cameras at work if they were to help

31 "Excerpts...," question 16.

32 "The sense...," 6. 
lower the threat of terrorism. Nevertheless, only one in three respondents would approve the methods that constitute the most serious interference in his or her liberty and privacy, i.e. control of property and placing cameras in homes in the presence of a terrorist threat. ${ }^{33}$ What this means is that Poles are willing to give up or limit some of their civic rights, but they question the need to give up their privacy in their daily lives (monitoring at home) to support the fight against terrorism.

The research results show that one in ten respondents does not approve any forms of interference with their civic rights and freedoms, which may be a cause of concern. One of the roles of a state is to assure the security of its citizens' and part of one's freedom should be sacrificed on the altar of said security.

\section{Conclusions}

In public awareness, terrorism is a fairly remote threat. Only a negligible percentage of the population (2\%) feels any significant concerns about terrorism. Terrorist attacks are not present in the social awareness of Poles and they only emerge as a threat once a third party mentions such a possibility. The threat of terrorist attacks is of the highest importance to women who live in Warsaw.

It should be noted that the Polish society is very strongly convinced that terrorism is not a real threat. On average, $75 \%$ of the respondents declared that the likelihood of terrorist attacks, bombings, and hostage-taking in Poland, is either very low or fairly low. Despite the small scale of threat, inhabitants of the Warsaw region are more likely to be concerned about it.

Terrorism is only rarely a source of a personal sense of insecurity. Only one in eight respondents $(13 \%)$ is concerned about terrorist attacks and bombings, to include $2 \%$ who have a high sense of insecurity. The society does perceive a hypothetical danger of terrorism, but when more closely faced with the problem, only a few express their concerns about becoming victims of terrorist attacks or bombings.

None of the respondents in the represented population had been a victim of the crime of hostage-taking. Only $1 \%$ of respondents declared that a close family member was a victim of hostage-taking, a terrorist attack, or a bombing. This demonstrates a marginal extent of victimization of Polish society by such crimes.

Public opinion on countering the threat of terrorism by the state and its organs is that it is quite satisfactory. Most respondents conceded that the state adequately counters the threat of terrorism. 
There is a high level of social acceptance of operational activities of state agencies aimed at eliminating the terrorist threat. Nearly $40 \%$ of respondents $(28 \%$ always and $10 \%$ in the exceptional situation of a terrorist threat) would allow the state to interfere with their privacy in the case of a terrorist threat. In situations of terrorist

threat, a fairly large group of respondents would be willing to accept covert operations of state agencies that would limit their privacy. As many as $67 \%$ of all respondents would accept tapping of their own phones. There is an increase in the acceptance level of telephone tapping and control of mail, to include electronic mail, in the presence of a terrorist threat.

\section{Annex}

Excerpt from the research tool - the Survey Questionnaire

1. Nowadays people encounter various threats that affect their sense of security. In your opinion, what threats are people most concerned about?

2. What threats are you, personally, most concerned about?

3. I will now read a list of various threats that one can encounter in daily life. Please tell me if you are concerned about them. Are you concerned about...?

\begin{tabular}{|l|c|c|c|c|c|}
\hline & $\begin{array}{c}\text { Definitely } \\
\text { concerned }\end{array}$ & $\begin{array}{c}\text { Rather } \\
\text { concerned }\end{array}$ & $\begin{array}{c}\text { Rather not } \\
\text { concerned }\end{array}$ & $\begin{array}{c}\text { Definitely not } \\
\text { concerned }\end{array}$ & It's hard to say \\
\hline Terrorist attacks & & & & & \\
\hline
\end{tabular}

9. Please tell me what is your opinion of the presence of these threats and social problems in Poland. Do you think that the threat... is very high, rather high, rather low, or very low in Poland?

\begin{tabular}{|c|l|l|l|l|l|}
\hline & Very high & Rather high & Rather low & Very low & $\begin{array}{c}\text { It's hard } \\
\text { to say }\end{array}$ \\
\hline Hostage-taking & & & & & \\
\hline Terrorist attacks, bombings & & & & & \\
\hline
\end{tabular}

10. Are you concerned about becoming a victim of the following threats?

\begin{tabular}{|c|c|c|c|c|c|}
\hline & $\begin{array}{c}\text { Definitely } \\
\text { concerned }\end{array}$ & $\begin{array}{c}\text { Rather } \\
\text { concerned }\end{array}$ & $\begin{array}{c}\text { Rather not } \\
\text { concerned }\end{array}$ & $\begin{array}{c}\text { Definitely not } \\
\text { concerned }\end{array}$ & $\begin{array}{c}\text { It's hard } \\
\text { to say }\end{array}$ \\
\hline Hostage-taking & & & & & \\
\hline A terrorist attack, a bombing & & & & & \\
\hline
\end{tabular}


Terrorism as a Current Threat...

11. Please indicate the threats of which at any time you or a member of your close family has ever been a victim.

\begin{tabular}{|c|c|c|}
\hline & The respondent was a victim & $\begin{array}{c}\text { A member of close family was } \\
\text { a victim }\end{array}$ \\
\hline Hostage-taking & & \\
\hline A terrorist attack, a bombing & & \\
\hline
\end{tabular}

12. Please look at the list of threats and indicate those that, in your opinion, the state does not counter adequately.

\begin{tabular}{|c|l|l|}
\hline & Indicated & Not indicated \\
\hline Hostage-taking & & \\
\hline Terrorist attacks, bombings & & \\
\hline
\end{tabular}

14. In your opinion, in the case of danger to citizens' security, is interference of the state with their privacy:

- always acceptable

- acceptable only in exceptional situations

- always acceptable

- it's hard to say

Respondents who pointed at the answer "acceptable only in exceptional situations" were asked question 14a.

14a. In what situations is interference acceptable? Please give examples of such situations.

16. In the fight against crime the state can use various forms of interference with citizens' privacy. Please tell me which of the following forms of interference you would be willing to accept if you or a member of your close family was threatened by a terrorist act, e.g. a bombing.

\begin{tabular}{|c|c|c|c|c|c|c|c|}
\hline $\begin{array}{c}\text { Telephone } \\
\text { tapping }\end{array}$ & $\begin{array}{c}\text { Mail } \\
\text { control, } \\
\text { to include } \\
\text { electronic } \\
\text { mail }\end{array}$ & $\begin{array}{c}\text { Checking the } \\
\text { content of } \\
\text { a computer } \\
\text { drive through } \\
\text { the Internet }\end{array}$ & $\begin{array}{c}\text { Control of } \\
\text { property }\end{array}$ & $\begin{array}{c}\text { Placing } \\
\text { cameras in } \\
\text { public places, } \\
\text { e.g. streets, } \\
\text { stores, parks }\end{array}$ & $\begin{array}{c}\text { Placing } \\
\text { cameras at } \\
\text { work }\end{array}$ & $\begin{array}{c}\text { Placing } \\
\text { cameras in } \\
\text { homes }\end{array}$ & None \\
\hline & & & & & & \\
\hline
\end{tabular}




\section{TERRORYZM JAKO WSPÓŁCZESNE ZAGROŻENIE DLA BEZPIECZEŃSTWA OBYWATELI}

Artykuł zawiera wyniki badań własnych dokonanych w 2008 r. w ramach realizowanego wówczas projektu badawczego noszącego tytuł: „Monitoring, identyfikacja i przeciwdziałanie zagrożeniom bezpieczeństwa obywateli”. Przebadano reprezentatywną próbę ponad tysiąca dorosłych Polaków, sondując respondentów w kilku obszarach bezpośrednio odnoszących się do zjawiska terroryzmu. W toku badań uzyskano odpowiedzi na szereg postawionych pytań. Ustalono, że terroryzm $\mathrm{w}$ zasadzie nie stanowi zagrożenia $\mathrm{w}$ świadomości społecznej i podobnie rzadko stanowi źródło zagrożenia osobistego poczucia bezpieczeństwa. Wynika to zapewne $\mathrm{z}$ faktu, że żaden $\mathrm{z}$ ankietowanych nie był bezpośrednio wiktymizowany atakiem terrorystycznym. Społeczeństwo dobrze ocenia działania organów państwowych podejmowane w celu przeciwdziałania zagrożeniu terroryzmem. Warto podkreślić, że Polacy reprezentują wysoki poziom akceptacji wobec czynności operacyjnych państwa działającego na rzecz wyeliminowania zagrożenia terroryzmem. $\mathrm{W}$ tym duchu gotowi są do rezygnacji z pewnych przysługujących im praw i wolności na rzecz przeciwdziałania zagrożeniom związanym z terroryzmem.

Key words:

Public opinion, citizens' security, threat, Poland 